\title{
On the Source of Ci-Priority Ideology of Wang Guowei’s Ci-Study and Ci-Creating
}

\author{
Wu Yana ${ }^{1} \&$ He Zongmei $^{1}$ \\ ${ }^{1}$ The college of arts, Southwest University, Chongqing, China \\ Correspondence: Wu Yana, The college of arts, Southwest University, No.2.Tiansheng Road, Beibei County, \\ Chongqing, China. Tel: 86-138-9622-4467. E-mail: wuyana1985@163.com
}

Received: August 7, 2015 Accepted: August 24, 2015 Online Published: September 21, 2015

doi:10.5539/ass.v11n26p178 URL: http://dx.doi.org/10.5539/ass.v11n26p178

\begin{abstract}
Wang Guowei was an important $\mathrm{Ci}$ researcher in the Ci-study field from the late Qing Dynasty to the early Minguo era who had developed the distinctive Ci-priority ideology. The Ci-priority ideology derived from 1) Wang Guowei's Ci-liking which had come from his individual character based on his melancholy and suffering experiences, 2) Wang Guowei's pure literature ideology which had surpassed fames and wealth, 3) Wang Guowei's sticking to and rejuvenating the traditional culture because of his thought and feelings that adherents of a former dynasty should behave with honor and dignity. Wang Guowei's Ci-priority ideology had introduce the West aesthetic theory of literature and art, and constructed the multi-angles and all-round system of Ci-study theory based on the core of prospect theory.
\end{abstract}

Keywords: Wang Guowei, Ci-priority ideology, pure literature ideology, thoughts and feelings of adherents of a former dynasty

\section{Introduction}

$\mathrm{Ci}$ is a kind of poetry written to certain tunes with strict tonal patterns and rhymes schemes, in fixed numbers of lines and words, originating in the Tang Dynasty and fully developed in the Dong Dynasty.

Up to the Qing Dynasty, the academic have continued to talk about the priority of various literature styles, but to time from the late Qing Dynasty to the times of Minguo, the ideology of superior poem and inferior Ci had not been thoroughly changed, so ci-priority could not enter the field of vision of literature history ${ }^{1}$. When one country is in reform and suffering, the poems and prose which can carry on the doctrine become the mainstream culture and are respected greatly, and ci becomes the end of literature and is neglected by the world. Wang Guowei develops ci-priority ideology under the circumstance of this ci-study development history and society changing and reforming. The academic have not interpreted where Wang Guowei's ci-priority come from. This is an important question which can not only find out Wang Guowei's academic thoughts and study-ci experience from micro-angle, but also can point out the changing and development of the ci-study, so it has very important significance to studying the ci field from the late Qing Dynasty to the early Minguo era.

\section{Wang Guowei's Individual Character of Melancholy and Suffering}

Wang Guowei's academic interests have changed with his physical condition and individual character. He has suffered from his experience. 'zhiyu yilai, shi you yunian, tis u leiruo, buneng ruijin yu xue, jin wu shiyou zhi zhu, tui you shengshi zhi lei, xing fu youyu, rensheng zhi wenti, ri wangfu yu wu qian, zi shi shi jue congshi yu zhexue' (“志学以来, 十有余年, 体素贏弱, 不能锐进于学. 进无师友之助, 退有生事之累”, “性复忧郁, 人生之问题, 日往复于吾前. 自是始决从事于哲学”) “He was sick for more than ten years from his beginning his study, so he could not improve his study greatly. He wanted to push forward his academic research, but he could not obtain the help from his teachers and friends. He had intent to give up the academic research, but he could not make living. So he has gradually become melancholy and depressed. He once said that making-living becomes a heavy burden which he must face every day, so he determined to undertake the philosophy study.' So, we find out that Wang Guowei took part in philosophy study because he wanted to get rid of the suffering and freed himself from worldly worries.

When Wang Guowei was absorbed in his philosophy study, he soon landed in terrible trouble which he considered that the philosophy theory is mostly lovely but not be trustful, and the trustful philosophy theory is 
not lovely. So he wanted to free himself from a predicament, but not be successful, and he has transferred his study interest from philosophy to literature.

At last, he focused on ci study after long-time lingering and thinking, and making successful in making poem and $\mathrm{ci}^{3}$. So Wang Guowei's success in making and studying ci should source to thin and weak physical, depressed character and resonating with ci's distinction which is good at expressing feelings. So Ye Jiaying (1988, p. 32) commented on Wang Guowei's and said that 'gai jingan xiansheng zhi weiren, fanxing guoduo, changyu yilian er duanyu fayang, ci suoyi ta sui yiyou wenxue zhi tiancai, er qi suochang zhe nai dan wei yi jingjian guya qusheng de shici'（盖静安先生之为人，反省过多，长于抑敛而短于发扬，此所以他虽亦有文 学之天才, 而其所长者乃但为以精简古雅取胜的诗词）'Mr. Jingan conducted himself in society based on his introspecting himself so much, so he was good at holding in and not good at throwing up, so this is the reason that he was good at making concise, ancient and elegant ci which was praised highly although he was a literature genius.'

Wang Guowei stressed the comfort function of aesthetics. He was influenced by Kant and Arthur Schopenhauer's aesthetics thought ${ }^{4}$, and he believed that art education has the function of 'wei kongxu zhi kutong, er fang beilie zhi shihao'慰空虚之苦痛, 而妨卑劣之嗜好 ${ }^{5}$, (to comfort the suffering-burden mind coming from the spiritual ballast, and free from the dishonorable and humble hobbies').

And Wang Guowei developed the art ideology that 'meiyu yu deyu buke li' (美育与德育之不可离 ${ }^{6}$ ) 'the art education and moral education cannot be divided.' So Wang Guowei was the first Chinese scholar who introduced the viewpoints that the art and literature are 'meishu zhe, shangliu shehui zhi zongjiao' (美术者，上 流社会之宗教 ${ }^{7}$ ) ‘the religion of the high society'. He considered that “' (美术之慰藉, 现实的也. 而美术之慰 藉中, 尤以文学为尤大，……故此后中学校以上, 宜大用力于古典一科 ${ }^{8}$ ) 'the function of art and literature is realistic, and literature is on the first place among the comfort function of the art and literature, so he advocated that people should endeavor to undertake the ancient and classic education from the middle school'.

Furthermore, Wang Guowei still believed that 'yiqie zhi mei, jie xingshi zhi mei' (一切之美, 皆形式之美 ${ }^{9}$ ) ‘all beauty came from the form beauty'. And the beauty of pictures and poems were all forms, so the tradition Ci-study which is famous for its form beauty is held in esteem because it is considered as inner feeling's reflecting from Wang Guowei himself. And Wang Guowei praised Li Yu (李显)that his ci had the same meaning and significance as Skaya Mani and Christ shoulder the human being's sins, and had the function of refining people's mind like religion. So we can say that $\mathrm{Ci}$ was praised highly because it could resonate with Wang Guowei's individual character.

\section{The Pure Literature Ideology of Transcending Fame and Wealth}

Wang Guowei was a famous scholar in early 20 century who had modern academics thought when he explored the nature of literature and law of creating and commenting on the literature during the upsurge of the west culture coming into the east culture. He focused on the art value on its own, considered that 'du mei zhi weiwu, shi ren wang yi ji zhi lihai err u gaoshang chunjie zhi yu, ci zui chuncui zhi kele ye’ (独美之为物, 使人忘一己 之利害而入高尚纯洁之域, 此最纯粹之快乐也 ${ }^{10}$ ) 'beauty could stand alone, it was a pure merry when it made people forget the fame and wealth and enter a high honorable and innocent scope'.

He established the pure literature ideology, and blamed that people used the art and literature as the political tools. And he believed that 'bi deng yan zhengzhi, ze yan zhengzhi eryier, er bi yu xie zhexue, wenxue zhi shensheng, ze ci da bukejie zheye' (彼等言政治, 则言政治而已耳，而必欲渎哲学、文学之神圣，则此大不可 解者也 ${ }^{11}$ ) ' it was not difficult to understand that people used politics to profane the sacred philosophy and literature'. He objected to imitating, and considered that 'mofang zhi wenxue, shi wenxiu de wenxue yu buzhui de wenxue zhi jihao ye' (模仿之文学, 是文绣的文学与餔飤的文学之记号也 ${ }^{12}$ ) 'the imitating literature was the literature signs of embroidering based on the fixed picture and eating the food from other's mouth'.

Wang Guowei did not like to write in ornate style when commenting Ci, and he believed if " (人能于诗词中不 为美刺投赠之篇, 不使隶事用典之句, 则于此道已过半矣 ${ }^{13}$ ) 'when one wrote $\mathrm{Ci}$ not to use ornate words and allusions, he mastered the main quintessence of creating and commenting $\mathrm{Ci}^{\prime}$. He disobeyed the literature ideology that literature should convey the moral viewpoints, and pursued the literature's aesthetic value which was seemingly useless. He often attacked the existing maladies when writing $\mathrm{Ci}$ over-using ornate words and the same meaning sentences. He criticized the evil of the Yangzhou Ci-style which advocated that the meaning and thought of $\mathrm{Ci}$ should be written in outer form of elaborate language. So he determined to clear the evil existing in the $\mathrm{Ci}$-field, and reestablish the new style of $\mathrm{Ci}$. He regarded the prospect and feeling as the two original natures of the literature, and then transfer them into meaning and prospect that could express oneself inner feelings and moves somebody from the outer angle. 
Wang Guowei's concepts of art and literature then converted into artistic ambience theory in his Renjian Cihua (人间词话), and loved, appreciated and advocated the natural, real and having- artistic-ambience Ci, so Wang Guowei brought the Ci-field with refresh wind. At last, we can see that Wang Guowei's Ci-priority ideology came from his pure literature concepts.

\section{Sticking to and Rejuvenating the Tradition Culture}

Wang Guowei came to Minguo as a adherents of a former Qing Dynasty, feeling sympathetic to the late Qing Dynasty. He called himself Donghai Yugong(东海愚公)after Xinhai Revolution(辛亥革命). He expressed his loyalty to the late Qing Dynasty by the means that he still sticks to the tradition culture. Traumas-devastation caused by Jiawu war had strengthened the uselessness concepts of the traditional culture. Yan Fu appealed 'bu du pohuai rencai zhi bagu yi chu, ju fan songxue hanxue, cizhang xiaodao, jie yi qie shu zhi gaoge ye' (不独破坏人 才之八股宜除, 举凡宋学汉学, 词章小道, 皆宜且束之高图也 ${ }^{14}$ ) 'to root out the Bagu which had destroyed the system of selecting talented people, and he called on placing the Song Cultuer, Han Culture and not-carrying-the-moral ci on the top shelf'.

The Qing Dynasty cancelled the Keju Kaoshi(科举考试—imperial examination system) by formal decree in 1905, and advocated the new style education and new political system. But the people of insight worried about the studies of classical Chinese culture disappearing from the time, they established series of newspaper printed for the tradition culture in order to 'kanfa baozhang, yongcun guoxue'(刊发报章，用存国学) 'establishing newspaper to protect the tradition culture'.

Wang Guowei and Luo Zhenyu established Guoxue Congkan based on this kind of ideology. And Wang Guowei still said that 'guojia yu xueshu wei cunwang, tian er wei yan zhongguo ye, bi bu wang qi xueshu'(国家与学术 为存亡, 天而未庈中国也, 必不亡其学术) 'country and academics could coexist, and the gods did not give up China, so they cannot destroy its academics.' So Wang Guowei believed that the academics had something with the country's existing, the men of insight should have courage to take on heavy responsibility to rejuvenate China traditional culture.

In fact, Wang Guowei majored in the west science in his early time, obviously, this was a thinking revolution because he considered that the most-valued literature of the east ancient country cannot be equal to the western literature, and we should wait for the future literati. Although Wang Guowei regarded advocating the traditional culture as his duty, he also bemoaned Ci's declining. He believed that 'zi nansong yihou, si dao zhi bu zhen jiu yi, yuan, ming ji guo chu zhulao, fei wu jingju ye, ran bumianhu jucu zhe, qi kun yu diaozhuo ye, jia dao yihou zhi ci, fei bu xie mei ye, ran wu jiu yu qianbo zhe, yi jie yu moni ye' (自南宋以后, 斯道之不振久矣! 元、明及国 初诸老, 非无警句也. 然不免乎局促者, 气困于雕琢也. 嘉道以后之词, 非不谐美也; 然无救于浅薄者, 意 竭于模拟也 ${ }^{15}$ ) 'Ci was not on the high ebb from Nan-Song Dynasty. Ci had some wonderful sentences from the Yuan and Ming Dynasty to the early time of Minguo, but it was distressed and embarrassed, and confined in ornate style. Ci was not inharmonious after the time of Emperor Jiajing and Daoguang in the Qing Dynasty, but it was considerably meagre and clumsily modelled on the former works'. And he had introduced Ci-style into the literature category which should be respected by the following persons.

Guo Yuanlin (2013, p. 19) said that Wang Guowei, 'jicheng qianjiaxuepai yanjin zhi feng bing jiejian xixue jingyao er kaichuang xinlu' (继承乾嘉学派严谨之风并借镜西学精要而开创新路 ${ }^{16}$ ) 'an academic giant, carried on the meticulous scholarship from Qian-Jia academic school, drawing lessen from the quintessence of the west science, and exploiting the new road to the academic peek'. Wang Guowei emphasized the discipline system very much. He believed that 'fan xuewen zhi shi, qi ke cheng kexue yishang zhe, bi bu ke wu xitong, xitongzhe he, li yixi er fenlei eryi'(凡学问之事, 其可称科学以上者, 必不可无系统. 系统者何? 立一系以分

类而已 ${ }^{17}$ ) 'anything about learning which can be called science must has a system, and what is the system? To establish series and can be divided into different categories.'

Wang Guowei had divided the beauty into 'elegant' and 'grand' because 'zi Bake ji Hande zhi shu chu, xuezhe dai shi ci wei jingmi zhi fenlei yi' (自巴克及汗德之书出, 学者殆视此为精密之分类矣 ${ }^{18}$ ) 'the academic regarded this as the elaborate categories after publishing Buck and Hande's books.' Wang Guowei used the view that 'one divides into two' into his artistic ambience theory, and strengthened the system of Ci theory. Directed by the west systematic thought, Wang Guowei integrated making $\mathrm{Ci}$, studying ci and rectifying the ancient documents onto himself, creating the systematic Ci-priority ideology.

\section{Conclusion}

The development of Wang Guowei's Ci-priority ideology had something with politics-culture environment from the late Qing Dynasty to the early time of Minguo, Wang Guowei's aesthetic concepts of the literature and art 
and Wang Guowei's individual character. Through exploring the source of Wang Guowei's Ci-priority concepts, we can find out that his Ci-priority concepts rooted in the traditional literature, based on the west aesthetics theory, and constructed the multi-angles and all-round theory system of Ci-study under the core of prospect ambience concepts.

Wang Guowei entered the traditional Ci field brought with new ideology, new thoughts and new methods, found the new road to new field for the Ci-priority's development. He liked a skylark in Ci field from the late Qing Dynasty to the early time of Minguo, who sang using his real and natural voice. He sang the first overture of the modern Ci-study loudly. When the falling flowers are flying in profusion in the sky, the whole trees turn into beautiful flowers. Wang Guowei advocated the evolution and reforming of Ci-study ideology during the Minguo times and modern times, Yang Haiming (1996, p. 110) said that Wang Guowei was worthy of the first person who had the cross-times significance during the new reforming of Ci-study and Ci-study criticism in the $20^{\text {th }}$ century.

\section{References}

Guo, Y. L. (2013). Do You Know the One-thousand-Year History of Grand When You Watching Daqin at the West Coast of Heihai-Wang Guowei Borrowing the Researching Method from the West Studies. The Knowledge of Classical Literature, 4.

Huang, R. (2015). The Literature History of China. Suzhou: the Publication House of Suzhou University.

Lin, C. J. (2013). Lin Chuanjia's Literature History of China. Changchun: The Publishing House of Jinlin Renmin.

Wang, G. W. (2007a). Author's Preface 1 of the 30th Chapter/ Yao Jinming. 2007. The Literature Collection of Wang Guowei (Last volume). The Publishing House of Zhongguo Wenshi.

Wang, G. W. (2007b). Author's Preface 2 of the 30th Chapter/ Yao Jinming. 2007. The Literature Collection of Wang Guowei (Last volume). The Publishing House of Zhongguo Wenshi.

Wang, G. W. (2007c). Brief Saying about Literature/Yao Jinming \& Wang Yan. The Literature Collection of Wang Guowei (Vol. 1). The Publishing House of Zhongguo Wenshi.

Wang, G. W. (2007d). On Getting Rid of Virus)/ Yao Jinming. 2007. The Literature Collection of Wang Guowei (Last volume). The Publishing House of Zhongguo Wenshi.

Wang, G. W. (2007e). On the Education Mission)/ Yao Jinming. 2007. The Literature Collection of Wang Guowei (Last volume). The Publishing House of Zhongguo Wenshi.

Wang, G. W. (2007f). On the Importance of Elegance to the Aesthetics/ Yao Jinming. The Literature Collection of Wang Guowei (Last volume). The Publishing House of Zhongguo Wenshi.

Wang, G. W. (2007g). On the Recent Academic Field)/ Yao Jinming. 2007. The Literature Collection of Wang Guowei (Last volume). The Publishing House of Zhongguo Wenshi.

Wang, G. W. (2007h). The Theory of Aesthetic Education Produced by Confucians/ Yao Jinming. 2007. The Literature Collection of Wang Guowei (Last volume). The Publishing House of Zhongguo Wenshi.

Wang, G. W. (2010). The Prelude to the General History of Europe/Xie Weiyang. 2010. The Literature Collection of Wang Guowei (Vol. 14). The House of Zhejiang jiaoyu. The Publishing House of Guangdong Jiaoyu.

Wang, G. W. (2013a). The Chapter 57 of Renjian Cihua / Zhou Xishan. The remarking, rechecking and collecting of Renjian Cihua. The Publishing House of Shanghai Sanlian Shudian.

Wang, G. W. (2013b). The Preface of Renjian Cihua/ Zhou Xishan. 2013. The remarking, rechecking and collecting of Renjian Cihua. The Publishing House of Shanghai Sanlian Shushe.

Yan, F. (1986). On the Saving the Nation from Extinction/Wang Shi. The Collection of Yan Fu (Vol. 1). The Publishing House of Zhonghua Shuju.

Yang, H. M. (1996). The Modern Process of theory of Ci-Study and Ci-Study criticism. Wenxue pinglun, 6.

Ye, J. Y. (1998). Wang Guowei and His Literature Criticism. Shijiazhuang: The Publishing House of Hebei Jiaoyu.

Zhou, X. S. (2013). The remarking, rechecking and collecting of Renjian Cihua. The Publishing House of Shanghai Sanlian Shudian. 


\section{Notes}

Note 1. When Lin Chuanjia commented the literature of the Song Dynasty, he only talked about poems, not talking about $\mathrm{Ci}$ in his work Zhongguo Wenxueshi in 1910. And during the same periods, Huang Ren also ignored the existing of $\mathrm{Ci}$.

Note 2. Wang Guowei. Author's Preface 1 of the 30th Chapter/ Yao Jinming. 2007. The Literature Collection of Wang Guowei. the last volume. p. 282. The Publishing House of Zhongguo Wenshi.

Note 3. Wang Guowei. Author's Preface 1 of the 30th Chapter/ Yao Jinming. 2007. The Literature Collection of Wang Guowei. the last volume. p. 284. The Publishing House of Zhongguo Wenshi.

Note 4. Wang Guowei. The Theory of Aesthetic Education Produced by Confucians/ Yao Jinming. 2007. The Literature Collection of Wang Guowei. the last volume. p. 93. The Publishing House of Zhongguo Wenshi.

Note 5. Wang Guowei. On Getting Rid of Virus/ Yao Jinming. 2007. The Literature Collection of Wang Guowei. the last volume. p. 14. The Publishing House of Zhongguo Wenshi

Note 6. Wang Guowei. The Theory of Aesthetic Education Produced by Confucians/ Yao Jinming. 2007. The Literature Collection of Wang Guowei. the last volume. p. 94. The Publishing House of Zhongguo Wenshi

Note 7. Wang Guowei. On Getting Rid of Virus/ Yao Jinming. 2007. The Literature Collection of Wang Guowei. the last volume. p. 14. The Publishing House of Zhongguo Wenshi

Note 8. Wang Guowei. On Getting Rid of Virus/ Yao Jinming. 2007. The Literature Collection of Wang Guowei. the last volume. p. 14. The Publishing House of Zhongguo Wenshi

Note 9. Wang Guowei. On the Importance of Elegance to the Aesthetics/ Yao Jinming. 2007. The Literature Collection of Wang Guowei. the last volume. p. 18. The Publishing House of Zhongguo Wenshi

Note 10. Wang Guowei. On the Education Mission/ Yao Jinming. 2007. The Literature Collection of Wang Guowei. the last volume. p. 33. The Publishing House of Zhongguo Wenshi

Note 11. Wang Guowei. On the Recent Academic Field/ Yao Jinming. 2007. The Literature Collection of Wang Guowei. the last volume. p. 21. The Publishing House of Zhongguo Wenshi

Note 12. Wang Guowei. Brief Saying about Literature/Yao Jinming \& Wang Yan. 2007. The Literature Collection of Wang Guowei. the last volume. p. 16. The Publishing House of Zhongguo Wenshi

Note 13. Wang Guowei. The Chapter 57 of Renjian Cihua)/ Zhou Xishan. 2013. The remarking, rechecking and collecting of Renjian Cihua. The Publishing House of Shanghai Sanlian Shudian. p. 228.

Note 14. Yan Fu. On the Saving the Nation from Extinction/Wang Shi. 1986. The Collection of Yan Fu. the first volume. The Publishing House of Zhonghua Shuju. p. 45.

Note 15. Wang Guowei. The Preface of Renjian Cihua/ Zhou Xishan. 2013. The remarking, rechecking and collecting of Renjian Cihua. The Publishing House of Shanghai Sanlian Shudian. p. 380.

Note 16.Guo Yuanlin. Do You Know the One-thousand-Year History of Grand When You Watching Daqin at the West Coast of Heihai-Wang Guowei Borrowing the Researching Method from the West Studies. The Knowledge of Classical Literature. Volume 4. p. 19.

Note 17. Wang Guowei. The Prelude to the General History of Europe/Xie Weiyang. 2010. The Literature Collection of Wang Guowei.volume14. p. 3. The Publishing House of Zhejiang jiaoyu. The Publishing House of Guangdong Jiaoyu.

Note 18. Wang Guowei. On the Importance of Elegance to the Aesthetics / Yao Jinming. 2007. The Literature Collection of Wang Guowei. the last volume. p. 17. The Publishing House of Zhongguo Wenshi.

\section{Copyrights}

Copyright for this article is retained by the author (s), with first publication rights granted to the journal.

This is an open-access article distributed under the terms and conditions of the Creative Commons Attribution license (http://creativecommons.org/licenses/by/3.0/). 